\title{
ANALISA PENGARUH KEMAMPUAN PENGANTAR AKUNTANSI DAN BAHASA INGGRIS TERHADAP PENILAIAN KEBERHASILAN PEMBELAJARAN MYOB (MIND YOUR OWN BUSSINES) DALAM MATA KULIAH KOMPUTER AKUNTANSI
}

\author{
Triadi Agung Sudarto \\ Dodik Juliardi \\ Universitas Negeri Malang \\ triadiagungsudarto@yahoo.com
}

\begin{abstract}
There are many factors that affect the value of the study subjects with MYOB accounting computer from students who had not yet attempted to optimally support improved learning outcomes. Some courses are a prerequisite for the accounting computer Introduction to Accounting I and Business English. Students S1 Accounting Education courses have difficulty in obtaining a satisfactory grade in the course computer accounting program MYOB. This is indicated by the presence of several factors that influence student success in obtaining a satisfactory grade, so research was done by looking at the main factors that cause the size of the final grade of the course computer accounting program MYOB. To see the influence of these two factors in this study used multiple regression analysis.
\end{abstract}

Keywords: Ability of Accounting Introduction, English Ability, Achievement MYOB

\begin{abstract}
Abstrak: Terdapat banyak faktor yang mempengaruhi nilai hasil belajar mata kuliah komputer akuntansi dengan MYOB dari mahasiswa yang selama ini masih belum diupayakan secara optimal untuk mendukung peningkatan hasil belajar. Beberapa mata kuliah yang menjadi prasyarat komputer akuntansi yaitu Pengantar Akuntansi I dan bahasa Inggris untuk bisnis. Mahasiswa program studi S1 Pendidikan Akuntansi mengalami kesulitan dalam memperoleh nilai yang memuaskan pada mata kuliah komputer akuntansi dengan program MYOB. Hal ini diindikasikan dengan adanya beberapa faktor yang mempengaruhi keberhasilan mahasiswa dalam memperoleh nilai yang memuaskan, sehingga penelitian ini dilakukan dengan melihat faktor utama yang menjadi penyebab besar kecilnya nilai akhir dari mata kuliah komputer akuntansi dengan program MYOB. Untuk melihat besarnya pengaruh ke dua faktor tersebut dalam penelitian ini digunakan analisa regresi berganda.
\end{abstract}

Kata Kunci: Kemampuan Pengantar Akuntansi, Kemampuan Bahasa Inggris, Prestasi Belajar Myob

Program MYOB accounting dibuat oleh suatu perusahaan yang bernama MYOB limited, sebuah perusahaan publik di Australia dan anak cabangnya MYOB US Inc. di USA. Program ini dijual dan dibuat oleh perusahaan sesuai dengan peraturan akuntansi dan perpajakan di negara dimana program itu dipasarkan. Program MYOB accounting yang sudah beredar sampai saat ini adalah program-program untuk kawasan USA, Australia, New Zealand, Afrika, Hongkong, dan Singapura. Hingga saat ini belum ada yang program MYOB accounting yang dirancang khusus untuk dipakai di Indonesia (Pramono, 2005). Meskipun 
demikian pemakai program di Indonesia bisa memakai program dari negara manapun dan kemudian memodifikasinya sendiri sesuai dengan standar sistem akuntansi yang dipakai di Indonesia.

Ketiadaan program MYOB accounting yang berbahasa Indonesia kemungkinan akan berpengaruh terhadap proses pembelajaran mahasiswa. Masalah yang sering terjadi adalah saat mahasiswa mengoperasikan program ini kemudian mengalami masalah atau kesalahan dalam pengoperasian, seringkali pesan kesalahan yang diberikan MYOB tersebut tidak dapat dimengerti oleh mahasiswa karena pesan itu tertulis dalam bahasa Inggris. Hal ini dipicu oleh kemampuan mahasiswa yang kurang baik dalam penguasaan bahasa Inggris. Oleh karena itu, diprediksi bahwa kemampuan bahasa Inggris mahasiswa berpengaruh terhadap keberhasilan pembelajaran MYOB.

Selain faktor kemampuan bahasa Inggris, faktor lain yang dianggap menentukan keberhasilan penguasaan MYOB accounting adalah faktor pengetahuan mengenai dasardasar akuntansi (Albertus, 2001). Pengetahuan tentang dasar-dasar akuntansi pada umumnya diberikan kepada mahasiswa ketika menempuh mata kuliah pengantar akuntansi. Dalam matakuliah pengantar akuntansi dibahas tentang identifikasi bukti transaksi sampai pelaporan keuangan (Kieso \& Wegandt, 2002). Tahapan di atas adalah langkah-langkah yang dilakukan untuk menyusun laporan keuangan secara manual. Dalam MYOB proses akuntansi tersebut akan diperpendek prosesnya. MYOB menyatukan pembukuan dan proses akuntansi, menyediakan jurnal, pemindahbukuan (posting) kode akun (kode rekening), laporan keuangan, dan analisa bisnis (Albertus, 2001) sehingga untuk membantu agar mahasiswa mudah memahaminya, mahasiswa harus menguasai terlebih dahulu dasar-dasar akuntansi yang tersaji dalam matakuliah Pengantar Akuntansi.

Dari paparan di atas, hipotesis yang diajukan dalam penelitian ini adalah sebagai berikut.

H1: Nilai Mata kuliah pengantar akuntansi I berpengaruh positif terhadap nilai akhir Mata kuliah komputer akuntansi yang menggunakan program MYOB.

H2: Nilai Mata kuliah Bahasa Inggris untuk bisnis berpengaruh positif terhadap nilai akhir mata kuliah komputer akuntansi yang menggunakan program MYOB. 


\section{METODE}

Penelitian ini merupakan penelitian eksplanatif dengan mengambil lokasi penelitian di Fakultas Ekonomi jurusan akuntansi Universitas Negeri Malang. Populasi penelitian adalah semua mahasiswa S1 Pendidikan Akuntansi yang sudah menempuh matakuliah Komputer Akuntansi MYOB. Sampel diambil berdasarkan kriteria berikut: (1) Mahasiswa program studi S1 Pendidikan Akuntansi; (2) Mahasiswa tersebut sudah pernah menempuh mata kuliah pengantar akuntansi I dan Bahasa Inggris untuk bisnis pada angkatan tahun 2011.

Model analisis yang digunakan dalam penelitian adalah analisis regresi berganda dengan variabel nilai akhir Mata Kuliah Komputer Akuntansi (Y) sebagai variabel dependen dan variabel Mata kuliah pengantar akuntansi I $\left(\mathrm{X}_{1}\right)$ serta nilai akhir Mata kuliah Bahasa Inggris untuk bisnis $\left(\mathrm{X}_{2}\right)$ sebagai variabel independen.

Persamaan regresinya dapat dituliskan sebagai berikut :

$Y=\beta o+\beta X_{1} \beta X_{2}$

$\mathrm{Y}=$ Variabel Nilai mata kuliah Komputer Akuntansi

$\mathrm{X} 1=$ Variabel Nilai Mata kuliah pengantar akuntansi I

X2 = Variabel Nilai Mata kuliah Bahasa Inggris untuk Bisnis

\section{HASIL DAN PEMBAHASAN}

Dengan menggunakan analisis regresi berganda dengan metode Ordinary Least Square diperoleh hasil yang terdapat dalam tabel dibawah ini untuk mahasiswa S1

Tabel 1. S1 Pendidikan Reguler dan Non Reguler:

\begin{tabular}{|c|c|c|c|c|c|c|c|c|}
\hline \multirow[b]{2}{*}{ Model } & & \multicolumn{2}{|c|}{$\begin{array}{l}\text { Unstandardized } \\
\text { Coefficients }\end{array}$} & \multirow{2}{*}{$\begin{array}{c}\text { Standardized } \\
\text { Coefficients } \\
\text { Beta }\end{array}$} & \multirow[b]{2}{*}{$\mathrm{t}$} & \multirow[b]{2}{*}{ Sig. } & \multicolumn{2}{|c|}{ Collinearity Statistics } \\
\hline & & $B$ & Std. Error & & & & Tolerance & VIF \\
\hline \multirow[t]{3}{*}{1} & (Constant &,- 580 & 1,818 & &,- 319 & ,752 & & \\
\hline & skor PA &,- 184 & ,250 &,- 192 &,- 736 & ,466 & ,306 & 3,272 \\
\hline & $\begin{array}{l}\text { skor } \\
\text { BHSIngg }\end{array}$ & ,102 & ,200 & ,085 & ,511 & ,613 & ,751 & 1,332 \\
\hline
\end{tabular}

a Dependent Variable: skor Myob 
Hasil regresi pada tabel 5.4 dapat digambarkan dalam model matematis sebagai berikut : Y = -0,580-0,184Skor PA + 0,102Skor BHSIngg +e

Tabel 2. Mahasiswa S1 Pendidikan Non Reguler

\begin{tabular}{|c|c|c|c|c|c|c|c|c|}
\hline \multirow[b]{2}{*}{ Model } & & \multicolumn{2}{|c|}{$\begin{array}{c}\text { Unstandardized } \\
\text { Coefficients }\end{array}$} & \multirow{2}{*}{$\begin{array}{c}\text { Standardized } \\
\text { Coefficients } \\
\text { Beta }\end{array}$} & \multirow[b]{2}{*}{$\mathrm{t}$} & \multirow[b]{2}{*}{ Sig. } & \multicolumn{2}{|c|}{ Collinearity Statistics } \\
\hline & & B & Std. Error & & & & Tolerance & VIF \\
\hline & (Constant & $-1,587$ & 2,060 & &,- 770 & ,453 & & \\
\hline & skor PA & ,466 & ,221 & ,423 & 2,109 &, 052 & ,847 & 1,180 \\
\hline & $\begin{array}{l}\text { skor } \\
\text { BHSIngg }\end{array}$ &, 154 & ,228 &, 147 &, 676 &, 509 &, 723 & 1,384 \\
\hline
\end{tabular}

a Dependent Variable :

Hasil regresi pada tabel 44 dapat digambarkan dalam model matematis sebagai berikut : $\mathrm{Y}=-1,587+0,466$ Skor PA + 0,154Skor BHSIngg + e

\section{Nilai Pengantar Akuntansi (SKOR PA) untuk Kelas S1 Pendidikan Reguler.}

Menurut hasil persamaan regresi yang diperoleh dengan melakukan pengujian hipotesis pertama terhadap variabel Nilai pengantar akuntansi (SKOR PA) terhadap Nilai Komputer akuntansi (SKOR MYOB) diperoleh t-hitung sebesar -0,736 dengan signifikansi 0,466 yang lebih besar daripada 0,05. Ini menunukkan bahwa variabel Nilai Pengantar Akuntansi berhubungan negatif dan tidak berpengaruh signifikan terhadap Nilai Komputer Akuntansi (Skor Myob), sehingga dalam pengujian parsial ini hipotesis yang diajukan ditolak. Temuan ini bertentangan dengan pendapat Albertus (2001) bahwa untuk mempelajari Mata Kuliah Komputer Akuntansi yang menggunakan MYOB diperlukan pengetahuan dasardasar akuntansi. Memang dalam praktiknya untuk dapat mengoperasikan Program $M Y O B$ accounting tidak diperlukan pengetahuan dasar tentang mekanisme akuntansi debit dan kredit sebagaimana yang dilakukan pada saat mencatat jurnal harian atau jurnal umum, karena 
jurnal harian atau jurnal umum hanya dilakukan pada proses pencatatan secara manual sehingga lebih dibutuhkan pengetahuan dasar-dasar akuntansi. Berbeda dengan pencatatan dalam program MYOB Accounting bahwa jurnal umum dan harian dapat dihasilkan secara otomatis tanpa melalui mekanisme pencatatan debit kredit. Pemakai Program MYOB Accounting hanya perlu memasukkan data-data transaksi pada menu aplikasi (form) yang sudah tersedia di dalam Program MYOB Accounting. Mungkin yang diperlukan oleh pemakai hanya pengetahuan mengenai akun (account) yang digunakan dalam pelaporan neraca dan Laporan laba rugi. Faktor lain pula yang dapat menyebabkan mengapa semakin rendah nilai yang didapat dalam Mata kuliah komputer akuntansi (SKOR MYOB) adalah rata-rata nilai mata kuliah pengantar akuntansi yang lebih rendah dibandingkan dengan ratarata nilai mata kuliah pengantar akuntansi pada Program S1 pendidikan non reguler.

\section{Nilai Pengantar Akuntansi (SKOR PA) untuk Kelas S1 Pendidikan Non Reguler.}

Menurut hasil persamaan regresi yang diperoleh dengan melakukan pengujian hipotesis pertama terhadap variabel Nilai pengantar akuntansi (SKOR PA) terhadap Nilai Komputer akuntansi (SKOR MYOB) pada kelas S1 pendidikan Non Reguler diperoleh t-hitung sebesar 2,109 dengan signifikansi 0,052 yang sama dengan 0,05. Ini menunjukkan bahwa variabel nilai pengantar akuntansi pada kelas Non reguler berhubungan positif dan mempunyai pengaruh yang signifikan terhadap Nilai Komputer akuntansi. Artinya semakin tinggi nilai yang diperoleh dalam Nilai pengantar akuntansi, semakin tinggi pula Nilai Komputer Akuntansi (SKOR MYOB) yang akan didapat oleh Mahasiswa S1 Pendidikan reguler. Hal ini menandakan bahwa dalam mengoperasikan program MYOB accounting dibutuhkan penguasaan terhadap dasar-dasar akuntansi. Temuan ini menguatkan konsep dari Albertus (2001) bahwa dalam penggunaan dan pengoperasian dari program MYOB accounting dibutuhkan pengetahuan mengenai dasar-dasar akuntansi. Ini juga bisa terlihat dari nilai 
hasil rata-rata yang diperoleh oleh kelas S1 Pendidikan Akuntansi Non Reguler. Hal ini menandakan bahwa kelas S1 Pendidikan Non reguler mahasiswanya lebih terpacu semangat belajarnya.

\section{Nilai Bahasa Inggris untuk bisnis (SKOR BHSINGG) untuk kelas S1 Pendidikan}

\section{Reguler dan Non Reguler.}

Hasil regresi dari melakukan pengujian hipotesa kedua untuk variabel Nilai Bahasa Inggris untuk bisnis (SKOR BHSINGG) terhadap Nilai mata kuliah komputer akuntansi didapat t-hitung 0,511 yang lebih kecil daripada T-tabel 1,980. Tingkat signifikan 0,613 yang lebih besar dari 0,05 yang berarti bahwa tinggi atau rendahnya Nilai Mata Kuliah Bahasa Inggris untuk bisnis tidak berpengaruh secara signifikan terhadap tinggi atau rendahnya Nilai komputer akuntansi. Sedangkan untuk kelas S1 pendidikan non regular didapat t-hitung 0,676 yang lebih kecil daripada T-tabel 1,980. Sedangkan tingkat signifikansinya 0,676 yang lebih besar daripada 0,05. Hasil penelitian ini bertentangan dengan pernyataan Pramono (2005) yang menyatakan bahwa meski belum ada program Accounting MYOB yang khusus dipakai di Indonesia ini tidak akan mepengaruhi Hasil Nilai akhir Mata kuliah komputer akuntansi. Ini menandakan bahwa Bahasa Inggris yang dipelajari dalam mata kuliah bahasa Inggris untuk bisnis yang dipelajari oleh Mahasiswa S1 Pendidikan regular dan Non Reguler materinya hanya memfokuskan pada penggunaan bahasa inggris untuk kepentingan bisnis saja dan tidak ada kaitannya dengan bahasa Inggris yang digunakan dalam Program MYOB accounting atau pengetahuan akuntansi lainnya yang berbahasa Inggris.

\section{Analisis Pengujian Secara Simultan}

Menurut hasil analisis regresi untuk kelas S1 pendidikan akuntansi Kelas reguler dari tabel dihasilkan $\mathrm{F}$ hitung sebesar 2,342 dan signifikan pada 0,053 pada tingkat $\alpha=0,05$. Hasil 
ini menandakan bahwa secara simultan semua variabel-variabel nilai mata kuliah pengantar akuntansi serta bahasa inggris berpengaruh secara signifikam terhadap nilai akhir mata kuliah komputer akuntansi atau dapat disimpulkan bahwa ada pengaruh yang kuat dari variabelvaribel nilai mata kuliah pendukungnya. Sedangkan untuk kelas S1 pendidikan akuntansi non reguler dari tabel $\mathrm{F}$ dihasilkan $\mathrm{F}$ - hitung sebesar 2,396 dan tingkat signifikan adalah 0,080 pada tingkat 0,05 . Hal ini juga menandakan bahwa secara simultan semua variabel-variabel nilai mata kuliah pendukung berpengaruh secara signifikan terhadap nilai akhir mata kuliah komputer akuntansi. Sehingga dapat disimpulkan disini bahwa pada kelas S1 Pendidikan akuntansi reguler variabel-variabel Nilai mata kuliah pengantar akuntansi, nilai Bahasa Inggris untuk bisnis mempunyai pengaruh yang signifikan terhadap Nilai akhir mata kuliah komputer akuntansi daripada S1 Pendidikan akuntansi non reguler.

Sedangkan untuk R-square sebesar 0,292 pada kelas S1 Pendidikan Akuntansi reguler menunjukkan bahwa 29,2\% dari variasi Nilai akhir mata kuliah komputer akuntansi dapat dijelaskan oleh variabel-variabel Nilai mata kuliah pengantar akuntansi serta nilai Bahasa Inggris untuk bisnis 70,8\% dijelaskan oleh variabel-variabel lain diluar model tersebut diatas. R-square untuk kelas S1 Pendidikan akuntansi non reguler sebesar 0,489 menunjukkan bahwa 48,9\% dari variasi Nilai akhir mata kuliah komputer dapat dijelaskan oleh variabelvariabel nilai mata kuliah pengantar akuntansi, nilai mata kuliah bahasa Inggris untuk bisnis, dan $51.1 \%$ dijelaskan oleh variasi-variasi lain diluar model diatas. Maka R-square yang lebih tinggi pada kelas S1 Pendidikan Akuntansi non reguler menunjukkan bahwa pada kelas ini variasi variabel dependennya dapat lebih dijelaskan dibandingkan dengan kelas S1 Pendidikan akuntansi Reguler. 


\section{KESIMPULAN}

Dari hasil analisa terhadap hasil pengujian hipotesis yang diuraikan pada Bab Sebelumnya, maka dapat ditarik suatu kesimpulan bahwa :1)Variabel Nilai Pengantar Akuntansi berhubungan negatif dan tidak berpengaruh signifikan terhadap Nilai Komputer Akuntansi (SKOR MYOB). Temuan ini bertentangan dengan pendapat Albertus (2001) bahwa untuk mempelajari Mata Kuliah Komputer akuntansi dengan MYOB accounting diperlukan pengetahuan dasar-dasar akuntansi.Memang dalam prakteknya untuk dapat mengoperasikan Program $M Y O B$ accounting tidak diperlukan pengetahuan dasar tentang mekanisme akuntansi debit dan kredit sebagaimana yang dilakukan pada saat mencatat jurnal harian atau jurnal umum, karena jurnal harian atau jurnal umum hanya dilakukan pada proses pencatatan secara manual sehingga lebih dibutuhkan pengetahuan dasar-dasar akuntansi. Berbeda dengan pencatatan dalam program MYOB Accounting bahwa jurnal umum dan harian dapat dihasilkan secara otomatis tanpa melalui mekanisme pencatatan debit kredit. Pemakai Program MYOB Accounting hanya perlu memasukkan data-data transaksi pada menu aplikasi (form)yang sudah tersedia di dalam Program MYOB Accounting. Mungkin yang diperlukan oleh pemakai hanya pengetahuan mengenai akun (account) yang digunakan dalam pelaporan neraca dan Laporan laba rugi.. 2) Variabel nilai pengantar akuntansi (SKOR PA) pada kelas Non reguler berhubungan positif dan mempunyai pengaruh yang signifikan terhadap Nilai mata kuliah Komputer akuntansi. Artinya semakin tinggi nilai yang diperoleh dalam Nilai pengantar akuntansi, maka akan semakin tinggi Nilai Komputer Akuntansi (SKOR MYOB) yang akan didapat oleh Mahasiswa S1 Pendidikan reguler. Hal ini menandakan bahwa dalam mengoperasikan program MYOB accounting dibutuhkan penguasaan terhadap dasar-dasar akuntansi yang baik. 


\section{DAFTAR RUJUKAN}

Kieso, D.E., Weygandt, J.J., dan Warfield, T.R. 2002. Akuntansi Intermediate. Jakarta. Penerbit Erlangga.

M.A., Nasution. 2003. Metode Research (Penelitian Ilmiah). Jakarta. Penerbit Bumi Aksara.

Ong, A. 2001. Menguasai MYOB Accounting 9. Jakarta. Penerbit PT. Elex Media Komputindo.

Mahmudi, Ali. 2004. Laporan Keuangan Semudah Klik Mouse MYOB Accounting Plus Versi 13. Yogyakarta. Penerbit Andi.

Pramono, P.R. 2005. Aplikasi MYOB Plus 13 pada bisnis manufacturing. Yogyakarta. Penerbit C.V. Andi Offset.

Rivai, H.V. 2000. Hasil Belajar Matematika Ekonomi Mahasiswa Fakultas Ekonomi. Surabaya. Survai di Fakultas Ekonomi Universitas Jayabaya Manajemen.

Sudharmanto, R.G. 2005. Trik Mudah Menguasai MYOB Accounting. Yogyakarta. Penerbit Graha Ilmu. 